\title{
Polkissen の組織學的及び組織化學的硎究
}

\section{第 1 報 Polkissen の一般構造}

千葉大學醫學部皮店科泌尿器科學教室

(指導 並木重郎教授)

原田澄

\section{HISTOLOGICAL AND HISTOCHEMICAL STUDIES ON POLKISSEN (ZIMMERMANN) I. REPORT HISTOLOGICAL STRUCTURE Kiyoshi Harada}

From the Dermato-Urological Clinic of Medical Faculty of Chiba University

(Director: Prof. Juro Namiki)

\section{緒言}

杉山1) (1924) は\#日鼠の腎細胞を中性赤で生體 染色すると，細尿管の間に篮基性色素分泌をなす 新しい細胞群を發見し，それは恐らく內分泌をな すものであろうと考え，之の細胞臂を朢小島(Niereninsel)之名付けた。妄之殆んど同時に Ruyter ${ }^{22}$ (1925)は Kopsch 液固定アルトマン氏ミトコンド リア染色法で處置した廿日鼠文び白鼠を觀察し絲 䟵體に侵入する輸入動脈壁の變異を發見した。郎 ち中層の滑平筋細胞は多いか少いか顆粒性上皮性 細胞となり，そのためにその部分の血管は肥厚し

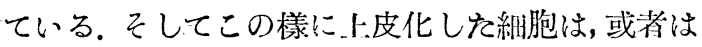
葉間動脈まで，或者は輸入動脈が絲正體まで侵入 したため, 絲毪體內まで侵入して存在することもあ る. こしてこの變異虫生後 1 週間で出來るもので, その意淺㳉恐らく絲速體の血流調篩に役立つもの であろうと云つた。併しながらこの樣な構造が人 及びその他の哺乳動物に存在することは否定し を. 彼はこの構造を epitheloide Muskelzellen と 名付けた。. 又Masson ${ }^{3)}(1924)$ 法皮下グロームスと 類似の棈造を有することを强㺃し，その類似性よ ๖，その生理的意莪をみつけた. 又 Mathis $^{4)}(1934)$

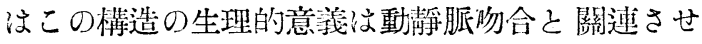
て論じている. Oberling ${ }^{5)}$ (1927)は Zenker-Formol 液で固定し Masson 氏 Trichrome染色法により 之と同樣な構造を人及び家嵬の腎に於て證明した
が原形質の顆粒狀態は見られなかつたと云う。次 いで v. Mollendorff $\left.{ }^{6}\right)(1930) も 〕 \sigma$ Handbuch に この構造に就て記载している Okkel`(1928) はこ の構造を蛙に於て墢見し, Goormaghtigh ${ }^{8)}(1932)$ は人及び猫に於て Zenker-Formol液固定 Masson 氏 Trichrome 染色に依り，絲逮體に信入する輸 大動脈のみならす。輸出靜脈に於て無纎維性細胞涪 を發見し之をLes Segments neuromyoarterieles juxtaglomerulaires du rein 已名付计. Zimmermann $^{9}$ (1933) は Ciaccio 氏液固定 Azan 染色 により輸入動脈に存在する特䅀な上皮性細胞样の 仔細な描竄をなしそしてその名稱をPolkissenと 名付け，多數の哺乳類郎ち人，䅺々の猿類，犬， 猫，熊，牛，はり好すみ，家霓等に於て之の構造 を發見し，之の構造が，特别の機能的意義を侍す る Baueigentumlichkeitであると述べ，その內分 泌性を暗示し，絲慦體に侵入する网血管に狹まれ そ細尿管の變異郎ち Macula densa との關連性を 示した. Schumacher ${ }^{10)}(1937)$ 岕この細胞臀より ヒスタミン樣の物質を分泌するのではないかと想 像した。そしてこの器管を非クローム㪘好性副交 感神經細胞であううと云う。 $\operatorname{Becher}^{11)}(1936)$ 泣 Polkissen の他に腎に於て內分泌學の存在を保證 し，それ神經性調節物質を分泌吉る。 そしてそ れはヒスタミン樣のもので，それにより血流調篩 作用をなすので沙ないかと想像した。るして 
Clara $^{12)}$ (1938) 结これらの細胞椎を- Goormaghtigh-Becher 細胞之名付けた. その後Goormagh$\operatorname{tigh}^{132}(1937,1938)$ 亦 L'appareil neuromyoarteriel juxtaglomerulaire du rein と細尿管の Ségment intercalaire 即ち Macula densa の一 部分とに常に解剖學的のアナローグの存在するこ とを强調し，その接觸部位に於て細尿管は特殊な 形態を取りこの兩者の間に機能的關連性のあるこ とを推测しを.

Goormaghtigh $^{14)}(1938 ， 1939 ， 1940)$ は火及び 笑鬼に就いて實驗的因子による影響在研究し，犬 の場合に於て虻正常の場合に於てもビタミンD過 剩の場合に於てを紐胞學的に內分泌機能を行する とは考えられないふ，家要の場合に於ては表居の これらの細胞整の或教が分泌顆粘を倠する。 そし てこれらの細胞は腦下淟體前葉のクローム咾好性 細胞の如く明らかに內分泌性の外觀を呈する。そ して义 Goldblatt 法を用いて家鬼及び大の腎に虚 血党起させると，本質的に變化するものはこれら

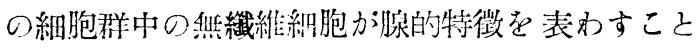
であつた.

Feyrter $^{15}(1940)$ : Bechersche Zellhaufen $の$

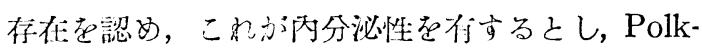
issen $\prec$ Bechersche Zellhaufen ¿Adventitielles nervös Geflecht ŁMacula densa との間に生物學 的關連性の存在することを强調した。. Dunihne ${ }^{16)}$ (1940) は Juxtaglomerular apparat の週期性分

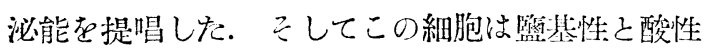
の顆粘を们し富血㹂の場合には酸性顆粒細胞の大 さと数は增大する。故に酸性顆粘は等望物質の源 であると云つを。烄尾 ${ }^{17)}$ (1942) は腎の微細構造 を㸴究し，その中で本細胞榤に棓及し，特にゴー ルヂー裝置，ミトコンドリア等に就いて形態學的

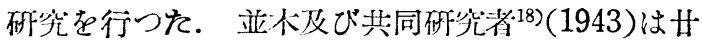
日鼠の Polkissen (epitheloide Muskelzellen)の 原形質內にら゙ンチアナ紫（クリスタル紫，メチー 儿紫）の稀釋溶液で染色される顆粒を發見し，そ の顆粒が核に由來するもので，分泌性を有するも のではないかとの暗示を與えた。 その門下山出 ${ }^{19)}$ (1946)は，この細胞群に對してなされた染色法を
比較して，ゲンチアナ紫法が最良であることを認 めた.そしてこの方法に低り㹂の正常及び實驗病 理學的の場合に於ける Polkissen の組織學的檢热 と骶のヒスタミンの生化學的定量法により Schumacher等の所謂ヒスタミンが Polkissenより分泌 されるのではないかとの說を否定した.

他方 Levene（I925）とその共同研究者は粘液蛋 白の化學を㡻究し，之等の化合物は常に或る組織 に現われる．コンドロイチン硫酸は身體の結締織 からのみ分離される。他方ムコイチン硫酸は廣い 分们を倠している. Levene は二つの主なる形一一 つは胢液腺の粘液, 血清の粘液卵粘液の中に, 他 の一つはWarton's jelly, 确子體液, 䐙膜の中に見 出されるもの一に分類した. その後Blix, Oldfeldt, Karlberg(1935) Meyer (1938)によつてその化學 が政究され，そしてメタクロマジーを起す色素が 粘液蛋白の染色法の中で最上のものであることが 制つた。この色素の粘液に對する親和力は非常に 大きいので稀釋した浴液で他の組織かがうじて

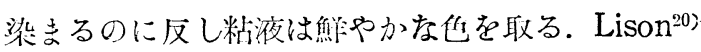
（1935）は之を多糖類硫酸エステルにその原因を求 めた。 そして留動脈の粘液變性の場合に表れると云 つているのは注目すべきである. Hempelmann ${ }^{21}$ (1940)は, トルイヂン青やポリクローメス・メチー レン青で染色し，25浯倍では，ムコイチン硫酸と コンドロイチン硫酸は网基染るが, 128 葸倍で岕 コンドロイチン硫酸しかそまらないとし，そこで

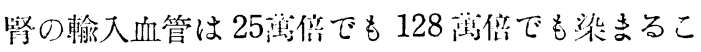
とを認めた。

又 Goldblatt 及びその他の著若22)の婜動脈の狹 窄による實驗的高血照症，そしてその機序が所謂 Renin に依ると云う說，又その Renin が輸入血 管より産出されるる云う說，そして又, 實驗的並 びに臨床的翅性高血洫症に於ける輸入血管の組織 學的變化に就いて，色々の興味ある事實か報告さ れている.

私は本報告に於て，此の構造の一般的組織學に 就いて述へんとする。 その他の所見に就いては次 の報告にゆづる. 


\section{材料の方法}

本研究に於ては成熟した廿日鼠 $18 \mathrm{~g}$ 內外のもの を使用し，

固定は純アルコール，Carnoy氏液 Ciaccio氏液 10\%フォルマリン,Champy氏液, Zenker-Formol 液で行い，3〜 $5 \mu$ のパラフイン切片を作製した.

染色は，ヘマトキシリン・エオジン, Azan(Heidenhain)染色, Masson 氏 Tricurome 染色のGoldner 氏變法 ${ }^{23)}$, Broster-Vines の Fuchsinophilia 染色 ${ }^{24)}$, van Gieson 染色, Weigert 染色, Foot 氏法, Golgi迅速法, Best 氏法, ゲンチアす紫法 (並朴)を以て一般構造を，10\%フォルマリン液固

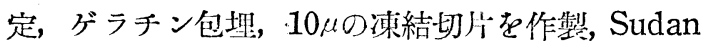
IIl Nilblausulfat, Ciaccio, Smith-Dietrich, Fisher 法を行い脂肪等の檢索をなしを。

\section{所見}

絲正體に传入する血管には 2 種ある，師ち輸入 動脈及び輸出動脈である。輸出靜脈力溥い壁を伤 し筋瀻維を有し交い構造を付する血管であるのに 反し，輸入動脈は良く發達した筋肉壁を付する血 管である。その中層をなす輸走する滑本筋細胞が

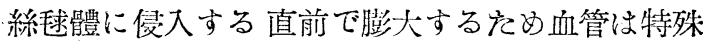
な形態を取当。之等の細胞臂が所謂 Polkissen (Zimmermann) 或いは L'appareil neuromyoarteriel juxtaglomerulaire du rein (Goormaghtigh)之呼ばれるものである。

ヘマトキシリン・エオジン染色では、マトキシ リンに依り核点，クロマチン，仁，核小體等は紫 に染まり，原形質はエオジンにより游漫性に淡紅 色に染まり顆粒狀態は見られない。そして留調が 細疗管，その他の部位と同一であり，又細胞境界 が不明膫であるためと結綗織瀻維が染色されない ので血管の外膜中層，內膜が 不朋膫で從つて， Polkissenの構造を確認するここは困難である：併 しながら輸大，輸出兩血管に狹まれた隅角に存在 する細痕管中間部の上皮細胞は他の細永管上皮細 胞及び輸入，輸出兩血管に狹れない部位の細尿管 上皮細胞よりも小さく秒々長い骰子狀で，その中 央に比較的大なる卵圓形乃至は圓形の核を付し， エオジンにより他の部位の原形質よりも淡く染
る.

純アルコール固定, Azan (Heidenhain)染色法 では結締織が良く染色されるので Polkissen の構 造が明睹となる。郎ち絲正體に侵入する輸入動脈 はその侵大する以前で中層の滑本紛細胞が大きく なるため漸次太くなつて絲逮體に侵入する，血管 內被細胞は長紡錘形で 血管榁にそつて縱走してい ろ。その核冲長楕圓形で帶裨出の赤色に染まるが 核の構造は明膫ではないが仁は赤色に染まる．細 胞原形質は青く染まつた結䋨織力;縱走して，それ に依り取㴻まれているので原形質に顆粒等の入る 餘地がない。その外周に輸走する中層の滑本筋細 胞が存在する。々の形は，卵圓形，圓形乃至は䯚 子狀である。そしてその大さは絲正體に近づくほ ぞ大きくなる，そして核は比較的大なる圓形刀至 卵圓形である。核犋は橙赤色に染まるが構造は明 膫でなく仁は赤く浓る．細胞原形質內には青色よ り紫色まで色々に染まる顆粒が多く橙色に染まる 顆粒は少々，赤色に染まる顆粒は殆んどない。こ の細胞の細胞慕は青く染まり，又內被細胞，外膜 細胞との間に結締織瀻維か一條乃至數條の繊維狀 となり青く染まつて縱走しているため內被細胞, 中層の滑平筋細胞，外膜細胞の細胞境界は明膫で ある，故に青く染るつた緎維は滑平筋細胞が䡒 走するをめその細胞榄をなす輪走するものと先に

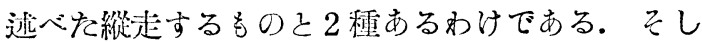

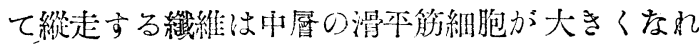
ば少莲となり，㱠んぞ細胞膜のみが染まつを樣に なり，中層の細胞が小さければ多くなり又太くな

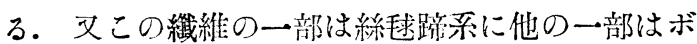
一マン氏被脱に偆大する，血管の外膜細胞は長紡 錘形で中央に長楕圓形の核があり，核は橙赤色に 染まり構造は明暸でない。細胞原形質は青くそま り縱走する結締䋊纖維により取圍まれているので 原形質は殆んどない。

血管膑，絲求體毛細管內にば魚紅色に染まつた 赤血球が存在する． 絲正體蹄系の結締織細胞は青 く染まり中央に楕圓形の楌が存在する．內被細胞 の核も橙赤色に染まる。輸出静脈は滑本筋細胞を

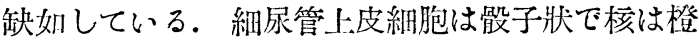


赤色に仁は赤色に染まり原形質は橙色の顆粒で充 滿し細胞膜は青く染る。輸入，輸出兩血管に陝ま

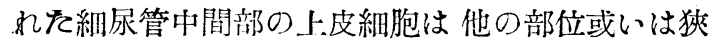
まれていない緗㽷管の上皮細胞よりも小さくなつ ている. そして原形質內に存在する顆粘の數も少 ない.

さて以上述べたのは輸入血管を縱斷した標本の 所見であるか，輸入血管を絲践體に侵入する直前

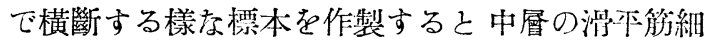
胞の形態とそしてそれによる Polkissen の構造が なお一層明膫となる。郎ち中層の埧平筋細胞は血 管を圍んでいる細胞が膨大したものであり，その

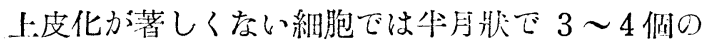
細胞が血管腔を囯んで存在する。.上皮化の著しい 細胞ではなお䐍大して，曲王狀少至は卵圓形とな

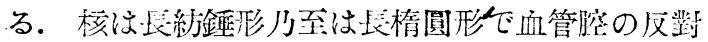
側におしやるれている。 そして原形質內に快請紫 也の顆粒が存在する。この絰胞の血管腔側には內 被細胞があり，それは核のみが約錘形に2〜3 存 在するのが制る方原形質は微少なをめ顆粘がをく

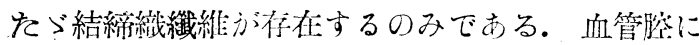
は赤血球が存在する，外膜細胞も核のみが中層の 細胞に附着した樣な 紡鍾形核で結締織繊維のみ見

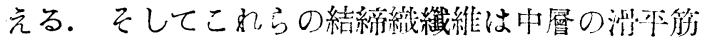
細胞の上皮化の著しい注に゙少數となる。

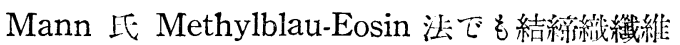
は肯くそまり，核，細胞膜も青く，原形筫は土オ

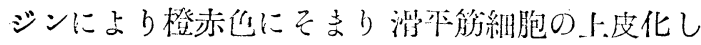
たものつ中には紫他の顆粠方存在する。 そして形

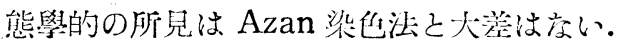

以上に述べた 2 種の染色洼は結縍緎を中心とし たものであつて Polkissen の顆粒はあまり明膫で はないので Polkissen の構造を砟䒕するのには適 賞ではない。

而し Ciaccio 上固定(水醋酸 $1 \%$ 以下) 2 日間 3 \%重ク口ム酸加里液で 7 日間Nachchromierung 友し Masson坻 Trichrome 染出の Goldner域變

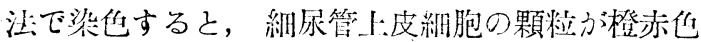
となるのに反し，Polkissenの顆粒はルビーやとな り單獨に Polkissen の細胞群を碓認することぶ出
來る。郎ち絲毪體に信入する輸入動脈はその侵入 する直前に於て中層の 棌本笳細胞が上皮化して膨 大するたり血管法漸次太くなる，血管つ內被細胞 は長紡錘形で血管膑にそい縱走しその細胞朕はう すい紫色に染りその中央にその長軸にそつて長棈 圓形の核か橙赤にそまるが核造構はあまり明膫て ない. 細胞原形質は殆んどなく從つて顆粒もない。 結絖織織維沙うすい紫出にそまつているが明膫て

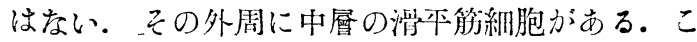

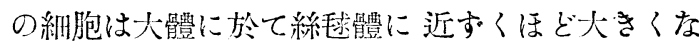
る.その形は卵圓形，圓形，歇子狀，曲玉狀をな す。核は圓形ないしは卵圓形で登赤色に染まゔて いるが核造構汶あまり明嘹で沶い。るれは維胞原形 質にはルビー色の顆粘が存在するためである。こ の原形筫內の顆䊀は綝胞により多數存在して原形 質に允滿するきのもあり，少少數しか存在しない 場合もある。この細胞の綝胞膜はうすく紫色に巳 まる。この細胞㴶の外同に縱走する外膜細胞があ る。その形恔紀錘形，その核は長楕圆形である。 核は橙色に己るり細胞点はうすい紫色である。こ れらの䋥胞は明瞭に區別されるが, 之は結締織瀻維 のためではなく，中層の溜本筋の細胞原形質の顆

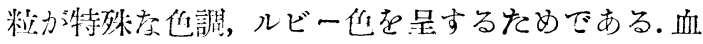

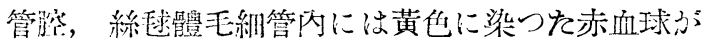
あり，ボーマン氏被䏚，絲正體蹄系の結締織瀻維及 び內被細胞は紫色に染り，その核は橙赤色にそま

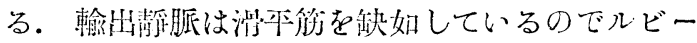

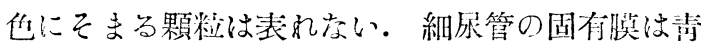
紫色に染去り他の隣接細名管之明膫に區別される が個々の絸尿管上皮絸胞の境想は明嘹でない，核 は橙赤色に染るがその桠造は不明膫である。原形

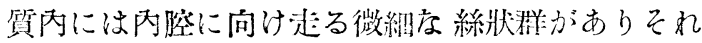
は腔に近すくに從つて顆粒狀となりその出調は核 より淡い橙赤出である.內腔之細尿管內皮細胞と口 間には青紫色に染まつた物質が存在する。輸大血 管圶橫斷した標本では形態は大體に於て Azan 法 と大差はないが,結蟐緎纎維が染まり難く，細胞の

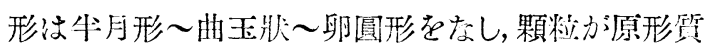
內に允滿しているものから散在しているものまで が存在することを明隌に涊め得当。又この染色法 
に依れば，中層の滑平筋細胞の上皮化一酸性フク シン好性顆粒の出現一は 血管の絲毯體に侵大する 直前の部位のみならす相當遠方まで，時としては 小葉間動脈の中層まで上皮化している 細胞が出現 することである。郎ち絲越體に近接した部位に顆 粘化した中層の細胞があり，次で顆粒化しない數個 の細胞があり，次で再び顆粒化した細胞が連續し たり，顆粘化しない細胞力゙連續している內に然然 に顆粒化した細胞か泏現したり，絲求體に侵入す る部位から小葉間動脈まで顆粒化している細胞が 存在する場合もある. そして顆粒化しない細胞も

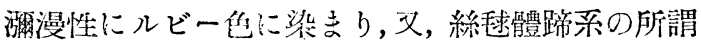
Mesangium が摴漫性にルビー色に染まつている. 又輸大動脈，輸出青脈に狄去れを隅角の維尿管上. 皮細胞の顆粒は他の部位の細尿管上皮細胞の顆粒

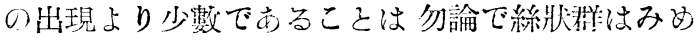
られない。

Ciaccio 上液固定(水醋酸 $1 \%$ 以下) 2 日間 $3 \%$ 重ク口ム酸加里 7 日間 Nachchromierung で, Broster-Vines の Fuchsinophilia 染色を行うと婜

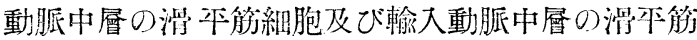
緗胞の顆粒と絲速體の Mesangium がルビー色子 なるのに反し 細尿管上.皮細胞の顆糔は赤褐出とな り後染色がアンリン青索ので，細胞境界，結蟐織

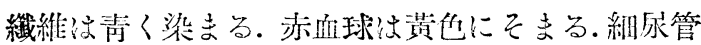
の內檫は雲彇に紫表色に染まる。そしてその他の 組織學的所見は Goldner紫渿法と同じであるがこ の方法では Mesangium と等動脈中層の涨漫性の 氿色は Goldner法より明膫である。この Goldner Broster-Vines 涊に依り Polkissenは Fuchsinophileの顆粘を份していることが制明する，又血管 $の$ 滑平筋細胞と Zimmermannの所謂Mesangium は同し好酸性の細胞であることが判る。

Champy 液固定，10盗倍ら゙ンチアナ紫法（並朴 等の方法による)で氿色するとPolkissen の顆粒は 紫に明膫に染まり他の如何なる 部位に於ても顆粒 が出現しないため，Polkissenの細胞群を全く單獨 に染色することが出來る，郎ち絲㲑體に侵入する 鐱入血管がその侵入する直前で中層の滑平筋細胞 が上皮化し膨大し卵圓形，圓形，骰子狀をなすを
め,血管が膨大する，血管の內被細胞は核が灰黑色 に鑛められているが細胞質は不明膫である。結䋨

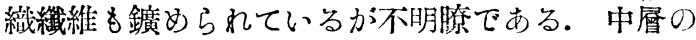
滑平筋細胞の核は灰色に仁は紫色に染められ，細 胞点は灰色に染められているが不明膫なので細胞 境界は從つて明らかでない，細胞原形質內には大 小不同，濃淡のある種々の顆粒が存在している. この顆粒は細胞質內に充滿している場合もあり。 そうでない場合もある。この樣に顆糔化した細胞 は絲求體より相當はなれを部位に存在し，はなは だしきときは小葉間動脈壁にまで及ぶときがあ

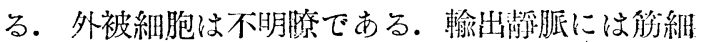
胞がない.從つて顆粒も仔在しない.ボーマン氏被

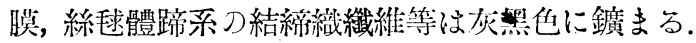
そして血管，絲速體內には灰色に鑛まつた赤血球 が存在する。組尿管は:皮細胞には紫色に染まつた 顆粒は存在しない，然し仁は紫に染まる。

van. Gieson 法で結締織瀻維を染色しても結果 はAzan 法より成續は不良で Polkissen の部位で は酸性フクシンにより染出される纎維は縱走する が少數である．中曆の滑平筋細胞はピクリン酸で

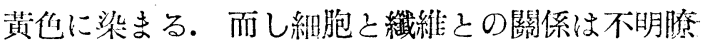
である.

Weigert 法で彈力纎維を染色すると，輸入血管 の內彈力臊は Polkissenの上皮化の著明で洨い場 合には絲垡體まで侵大しているのが認められる。 ぶ，上皮化の著明なものでは Polkissen の部分で 溜失している樣に見える。

Foot 氏 Reticulum染出法で鑛銀を施し，へマ トキシリン・エオヂンで複染色をなすと Azan, Mann, van Gieson 法では染出出來ない嘫銀性緎 維が存在する.この繊維は形態學的に 2 種に區別 される。

一つは輸大血管の長朝に沿つて 走る比較的太い 瀻維で他の一つは血管を橫斷して血管にもつれあ つている多數の微細な瀻維である. 後者の微細な 織維は前者の太い瀻維間を連絡するのみならす, 後者相互間をる連絡し，一部は絲正體まで侵入し ている. 而しこれらの譛銀性繊維の中に神經繊維 が合まれているかどうかは決定出來ない。 
策１疄] 阁定アルコール

染他 Azan (Heidenhain) $\times 690$

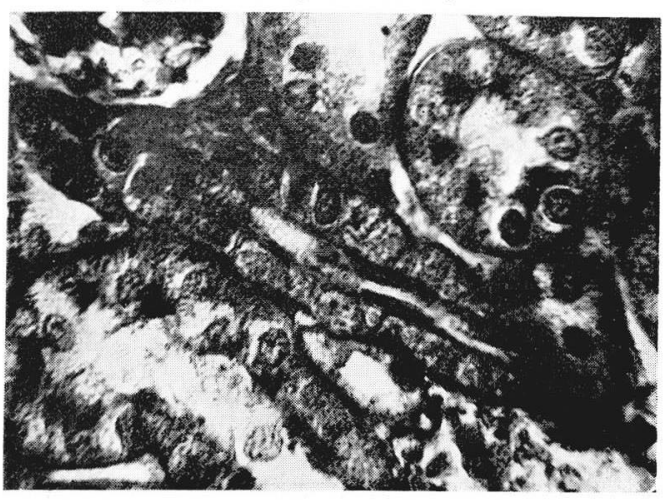

第 2 圖 固定 Ciaccio 染色 Masson D

Trichrome 法の Goldner 镍法 $\times 690$

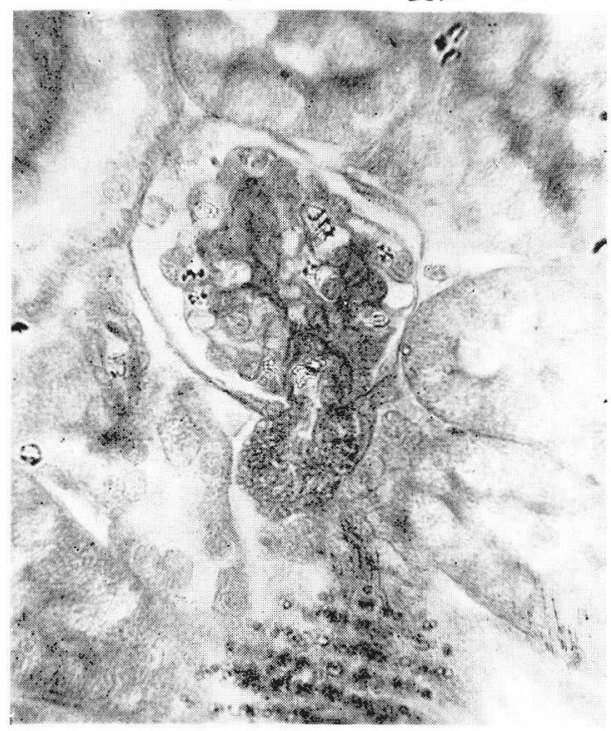

第 3 圖 周定 Ciaccio

染色 Broster-Vines 法× 690

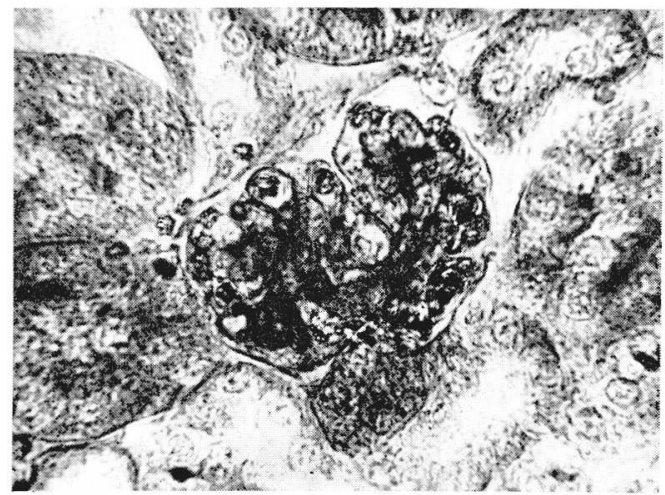

第, 4 圖 周定 Ciaccio 染色 Goldner 法

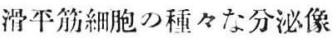
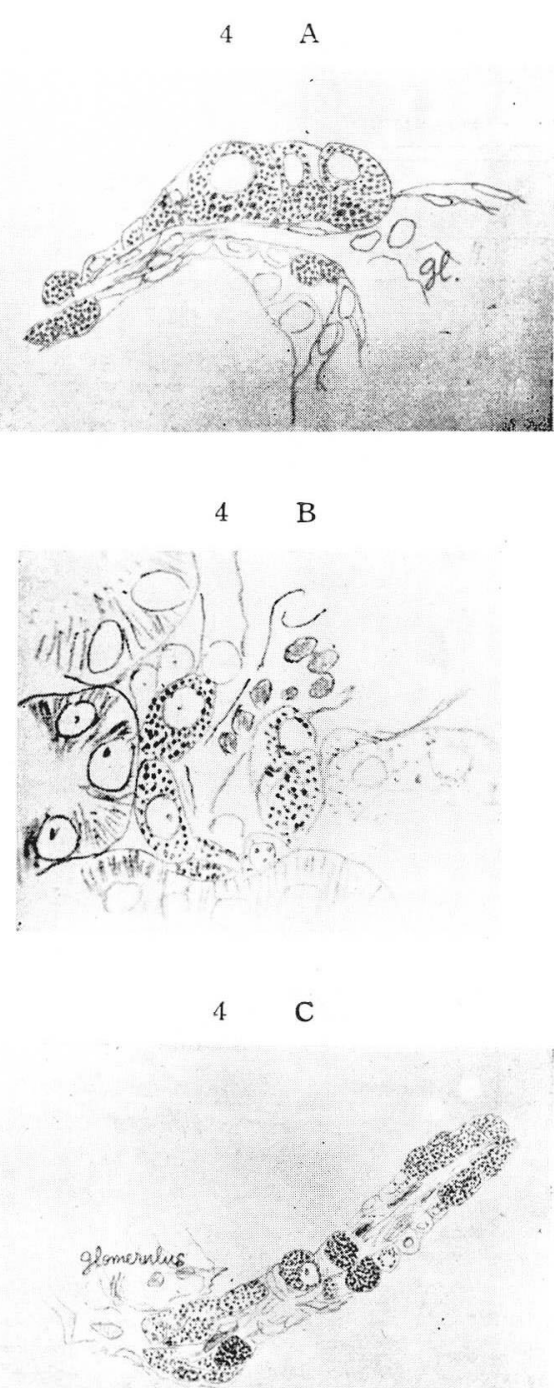

$4 \quad \mathrm{D}$ 
$4 \quad \mathrm{E}$
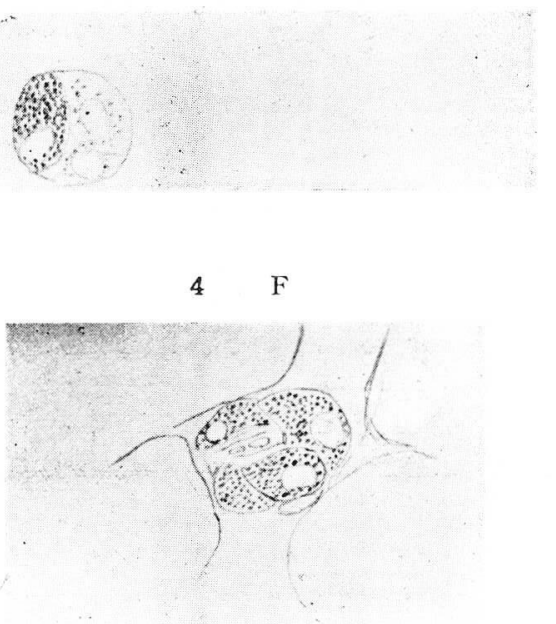

$4 \quad$ G

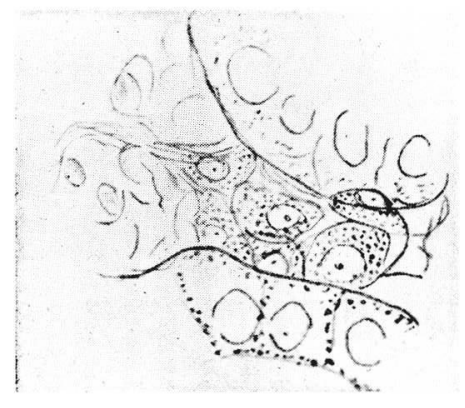

第 5 圖 固定 Champy

染色 $100000 \propto$ Gentianaviolett 法

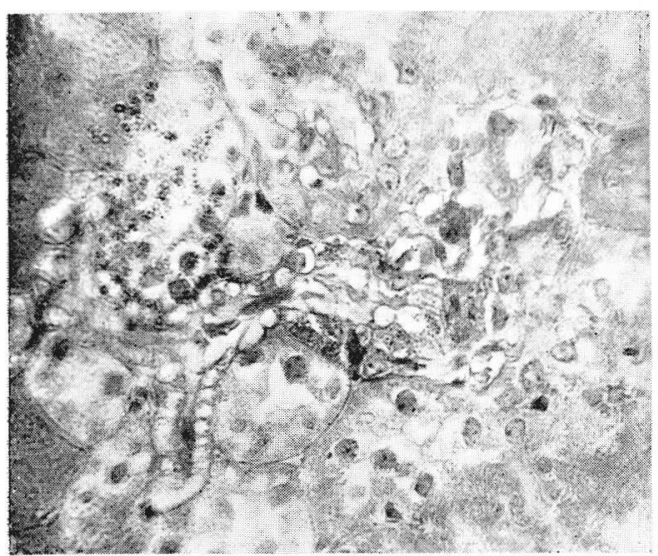

第 6 圖 周定つォルマソン

染色 250000 Gentianaviolett 法

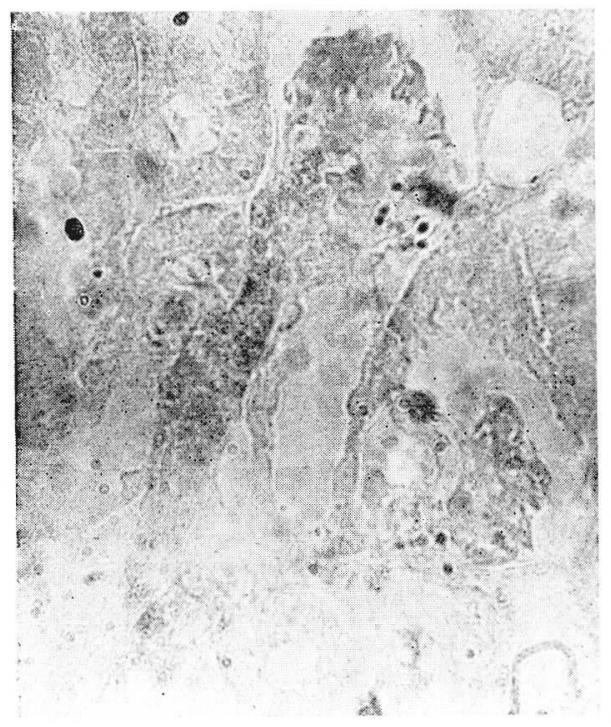

第 7 圖 Kopsch-Kolatschew 法

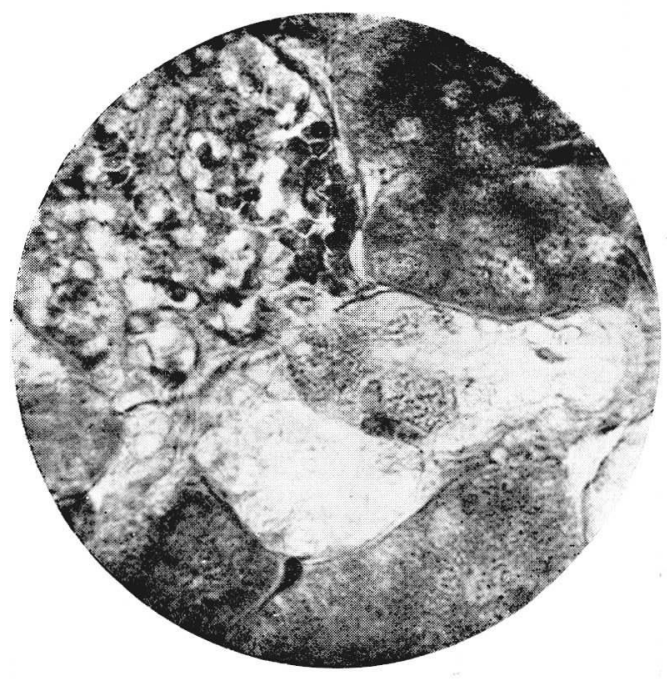


第 8 圆 Pol Kissen の模型

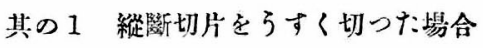
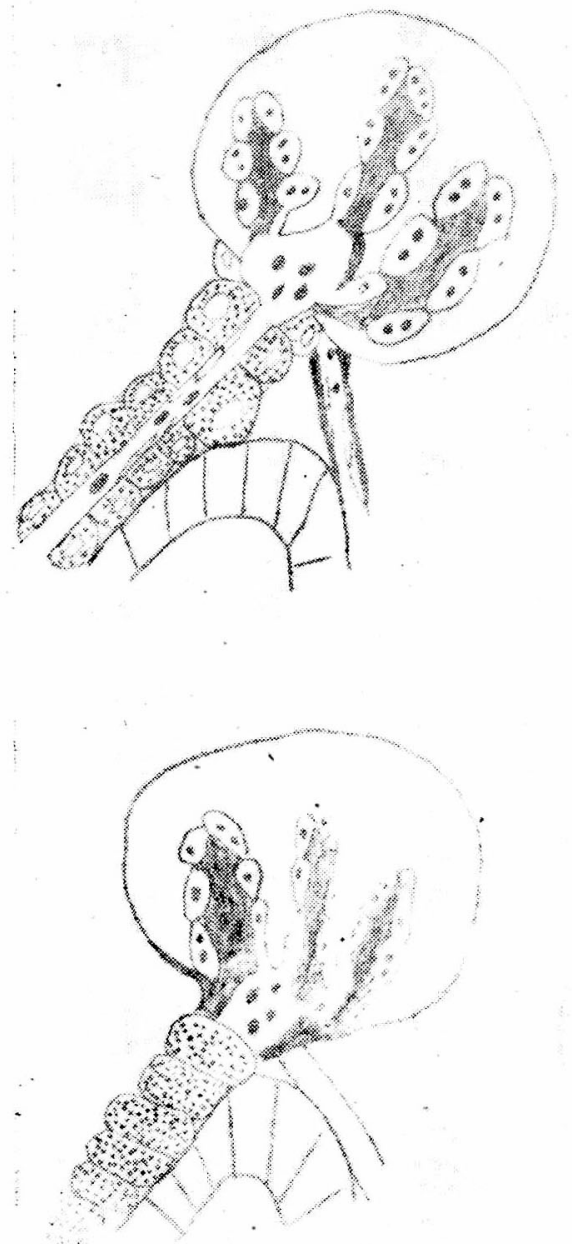

切片をあっく切つけ場合

\section{其の 2 橫斷}

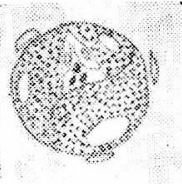

III

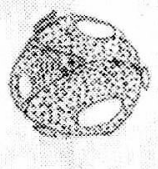

II

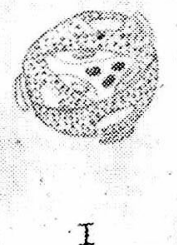

I
そこで Golgiの神經瀻維鈸銀法を試みると Foot

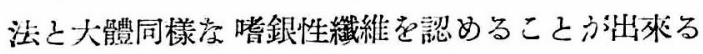

か，この場合には縱走する織維は前者の場合より 絧い. 而しこの染出法は複染色法力出棑ないので 䦖图の組織との關係は不明であり，满本は值ちに 褪出するので良い方法ではなかつた。 そして，こ

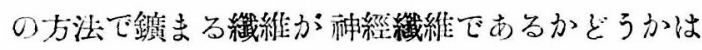
洪定困難である.

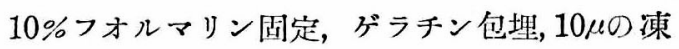
切切个を作製し Sudan III, Nilblausulfat で脂肪 染他をなすと Pol Kissenの上皮化の著しい細胞 群に於ては游漫性にうすく Sudan III 若くはNilblausul「atでリポイドが染色されるが,切版厚い ので顆粒狀態は認められなかつた. 然しながら Ciaccio 氏滛で固定パラフイン切片でSmith-Dietrich 法をなすと，顆粒狀態力認わられる。 又 KopschKalatschew 法で Golgi 染染しPal 螁出法を施

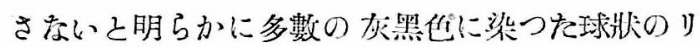
ポイド顆稙が絸胞原形質に允漰しているのを見出 す．而し輸出血管にはリポイド顆粒は認められな い。そしてメ兩血管に狹まれを部位の細尿管上皮 絸胞に於てもリポイド顆粘が少いことが碓認出來 る. Carnoy氏液て圆定しBest域の Glykogen染色

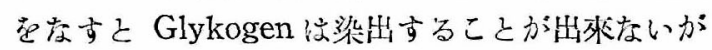
Bauer-Feulgen 法で Glykogen 少量染出する こと拙來る。

\section{考案}

以上の所見により私はPol Kissenの細胞渞の形 態學は滑本解細胞の上皮化と云う見方よりは $\mathrm{Ma}$ sson の Trichrome 染色の Goldner の變注, Borster-Vines 0 Fuchsinophilia 泾出法, Gentianaviolett 法わ㵊適である。これらの方法に低る 之, 洲平筋細胞の上皮化は絲逮體に大る輸入血管 の優入する直前の部位ばかりではなく，それより 相當遠い部位の葉間，小葉動脈に於ても上皮化が 存在することがある。 Becherか獨立の器官とした のはからる部位の血管を横斷したとき，上皮化し

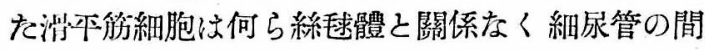
に表れるからであろう。文杉山が Niereninsel と したのも最初にこの樣な細胞群が筱組織の中で岛 の樣に見えたからであろう。

故にPol Kissen 細胞群の形態は單純に杉山の云 
う樣に，圓柱型と卵圓形型に區別出來るものでは なく，滑平勄細胞の上皮化の程度とその部位によ り。色々に變化する。

そしてPol Kissen を形成する個々の滑平労細胞 の形態に就いては色々の硼究者により，種々の形 態があると云われてきた。然しながらこれは動脈 の中層をなす滑平紛細胞が上皮化したすのである こと〉，中首をなす滑平筋細胞は血管を圍み輸走 している細胞であることを忘れている結果で，切 片の七斷方向と厚さにより變つた形態を取ること は必然である。

血管を栱斷した切片では，血管腔を圍んで非月 形より漸次膨大して 卵圓形となる $3 \sim 4$ （まれに 5) 個の細胞群である.膨化が一方にかたよれば, 曲玉狀になる，血管を縱斷した切片では，小丘狀， 卵圓形，圓形，骰子狀と次第に膨化した細胞が血: 管腔の兩側に併列する.

上皮化した埧本筋細胞の細胞原形質には好酸性 顆粒，好鹽基性顆粒が同時に存在する。この顆粒 の組織化學に就いては後述する。

結締織織維の消長より本細胞整を見るには Azan法が最䢛で Methylblau-Eosin法 van Giesonか; そに次ぐ，そして細胞との關連して考えるのは Azan 法でなりねばならない。而し絲求體から離 れた部位の構造はあまり明膫でない。そして緎維 の多少により從來 paucifibrillar cell, afibrillar cell に分類されているか， それは明嘹に區别され ることはなく段階がある。

又, Broster-Vines の Fuchsinophilia染色法に より, 絲笺體の Möllendorff の所謂 Deckzellen, Zimmerman の Mesangiumそして McManus ${ }^{25}$ の Intercapillary Spaceと云われるものがPol Ki-

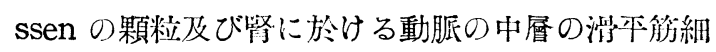
胞と同樣に Fuchsinophiliaに染まることはこれら の細胞が同一系統に屬するもので，絲顆體の_皮 細胞や結締織細胞及び Pericyten と關係のないこ とが制明する。

そして Pol Kissen の機能は血管及び絲正體の 機能を中心として考えなければならないことぶ制 る.

\begin{abstract}
結論
Pol Kissenの變異は形態學的に血管の滑平筋細 胞の上皮化でるる。從つて結縍織緎維の減少ない しは消失が起る。そして又機能的に血管と絲球體 を閵連させて考えねばならない。

(詳細な檢討は最後の報告にまとめる豫定)

御指導して下さつた恩師並木教授に感謝します。
\end{abstract}

\section{文獻}

1)杉|山, 角, 福田：日本病理學會誌, 32,1942. 33,1943. -2) Ruyter, J.H.C.: Ztschr. f. mikr-anat. Forsch., 2, 242, 1925. - 3) Masson, P.: Les gl omus vasculaires, dans Policard, H.; Histophisiologie, Paris J. Hermann. 1937. - 4) Mathis, J.: Winer Klin. Wochenschr., 48, 1444, 1934. - 5) Oberling, C.R.: C. R. Acad. Sci. Paris, 182, 1200, 1927. -6) Möllendorff W. v.: Der Exkretionsapparat, Handb. d. mikrosk. anat. d. Menschen, 7, Teil, Springer. 1930. -7) Okkels et Peterfi: Zeitsch. f. Zellforsch 9, 327, 1927. -8) Goormaghtigh, N.: Arch. Biol., 43, 575, 1932. -9) Zimmermann, K.W.: Ztschr. f. mikr.-anat. Forsch., 32, 176, 1933. - 10) Schumacher, S.: Ztschr. f. mikr.-anat. Forsch., 43, 1938. - 11) Becher, T.: Ztschr. f. wiss-Mikr., 53, 206, 1936. -12) Clara, M.: Mü-nc h. med. Wochenschr., 16, 1936. - 13) Goormaghtigh, N.: C.R. Soc. Biol. Pariss., 124, 293, 1937. Goormaghtigh, N.: Jour. of. Physiol., 90, 1263, 1937. - 14) Goormaghtigh, N. et Handovsky, H.: Arch. of Path., 26, 1144, 1938. Goormaghtigh, N. et Pannier, R.: Arch. Biol., 50, 455, 1939. Goormaghtigh, N.: Am. J. Path., 16, 409, 1940. 15) Feyter, F.: Virchow Arch., 306, 135, 1940. -16) Dunihne, F.W.: Anat. Rec., 73, 64, 1939. Dunihne, F.W. and Candon, B.H.: Arch. of Path., 29, 777, 1940. 一 17) 長尾: 熊本醫學會誌, 17, 9, 1941. - 18) 並木, 中村, 水落, 本多, 原田: 日泌尿會哂，36，1，1943。-19）山田：日泌尿會 誌に墢表の豫定. 一20). Lison, L.: C.R. Soc. Biol. Paris., 118, 821, 1935. - 21) Hempelmann, L.: Anat. Rec. 78, 197, 1940. - 22) Cardio-Vascular System, Arterial Hypertension (Recent Advances in Pathology. J. \&. A. Churchill Ltd. London., 1948). - 23) Goldner, J.: Am. J. Path.. 14, 237, 1938. - 24) Broster, L. R. and Vines, H,W.C.: The adrenal cortex: A surgical and pathological Study, London. H. K. Lewis \&. Co. Ltd., 1933. - 25) Mc Manus: Am. J. Path., 24, 643, 1948. Mc Manus: Am. J. Path., 24, 1259. 1948. 